\title{
Modulating the distribution and fate of exogenously delivered MSCs to enhance therapeutic potential: knowns and unknowns
}

\author{
Claire H. Masterson ${ }^{1,2}$, Gerard F. Curley ${ }^{3}$ and John G. Laffey ${ }^{1,2,4^{*}}$ (D)
}

From The 3rd International Symposium on Acute Pulmonary Injury Translational Research, under the auspices of the: 'INSPIRES ${ }^{\oplus 1}$

Amsterdam, the Netherlands. 4-5 December 2018

* Correspondence: john.laffey@
nuigalway.ie
${ }^{1}$ Regenerative Medicine Institute
(REMEDI) at CÚRAM Centre for
Research in Medical Devices,
Biomedical Sciences Building,
National University of Ireland
Galway, Galway, Ireland
${ }^{2}$ School of Medicine, College of
Medicine, Nursing and Health
Sciences, National University of
Ireland Galway, Galway, Ireland
Full list of author information is
available at the end of the article

\section{Springer Open}

\begin{abstract}
Mesenchymal stem/stromal cells (MSCs) are undergoing intensive translational research for several debilitating conditions, including critical illnesses such as ARDS and sepsis. MSCs exert diverse biologic effects via their interaction with host tissues, via mechanisms that require the MSC to be in close proximity to the area of injury. Fully harnessing the therapeutic potential of advanced medicinal therapeutic products such as MSCs and their successful translation to clinical use requires a detailed understanding of MSC distribution and persistence in the injured tissues. Key aspects include understanding MSC distribution within the body, the response of the host to MSC administration, and the ultimate fate of exogenously administered MSCs within the host. Factors affecting this interaction include the MSC tissue source, the in vitro MSC culture conditions, the route of MSC administration and the specific issues relating to the target disease state, each of which remains to be fully characterised. Understanding these factors may generate strategies to modify MSC distribution and fate that may enhance their therapeutic effect.

This review will examine our understanding of the mechanisms of action of MSCs, the early and late phase distribution kinetics of MSCs following in vivo administration, the ultimate fate of MSCs following administration and the potential importance of these MSC properties to their therapeutic effects. We will critique current cellular imaging and tracking methodologies used to track exogenous MSCs and their suitability for use in patients, discuss the insights they provide into the distribution and fate of MSCs after administration, and suggest strategies by which MSC biodistribution and fate may be modulated for therapeutic effect and clinical use.

In conclusion, a better understanding of patterns of biodistribution and of the fate of MSCs will add important additional safety data regarding MSCs, address regulatory requirements, and may uncover strategies to increase the distribution and/or persistence of MSC at the sites of injury, potentially increasing their therapeutic potential for multiple disorders.
\end{abstract}

Keywords: Mesenchymal stromal cell, Biodistribution, Kinetics, Fate, Cell distribution, Cell imaging 


\section{Background}

Mesenchymal stem/stromal cells (MSCs) were first described in the 1970s as a clonogenic fibroblast precursor cell population of the bone marrow, referred to at the time as 'colony forming unit fibroblasts' [1,2]. These cells were plastic adherent, had a fibroblast-like morphology, could be differentiated down chondrogenic, osteogenic and adipogenic lineages [3], and continuously expanded ex vivo [4]. MSCs can now be isolated from other tissue sources including adipose and placental tissues. Current MSCs identification strategies utilise their expression of cell surface markers, and their ability to differentiate down mesoderm (chondrogenic, osteogenic, adipogenic) lineages [3]. MSCs are positive for CD105, CD73, CD44, CD90 and negative for CD45, CD34, CD14 (i.e. haematopoietic markers), CD11b, CD79 $\alpha / C D 19$ and HLA-DR [3].

Unfortunately, for a number of disease targets, promising results demonstrated in diverse pre-clinical models have to date largely not successfully translated in subsequent phase 2-3 clinical trials [5]. Understanding the reasons underlying prior translational failures for cellular therapies may improve the likelihood of subsequent success, including for critical illnesses such as sepsis [6] and ARDS [7]. A significant knowledge gap has been the understanding of the biodistribution of MSCs following exogenous administration, and of their ultimate fate within the host.

A better understanding of patterns of biodistribution and of the fate of MSCs will uncover strategies to enhance strategic targeting and/or persistence of MSC at the sites of injury, potentially increasing their therapeutic ability. However, determining the biodistribution and fate of MSCs is clearly more challenging than for a standard pharmacologic. In this regard, recent advances in imaging techniques now offer the possibility to more systematically develop our understanding of these issues.

Fully harnessing the therapeutic potential of advanced medicinal therapeutic products such as MSCs and their successful translation to clinical use requires a detailed understanding of MSC distribution and persistence in the injured tissues. This review will examine our understanding of the mechanisms of action of MSCs, the kinetics and dynamics of MSCs in vivo, and the potential importance of these to mediating the effects of MSCs. We will critique the cellular imaging and tracking methodologies currently used to track exogenous MSCs, discuss the insights they provide into the distribution and fate of MSCs after administration, and suggest strategies by which MSC biodistribution and fate may be modulated for therapeutic effect.

\section{MSCs mechanisms of action}

MSCs exhibit a diverse array of effects and multifunctional mechanism of action, with no single, overarching biological effect. The precise mechanisms by which MSCs modulate the injury or reparative processes appear to depend on the specific injury microenvironment and the pathobiology of the injurious/repair process itself. MSCs appear to act predominantly by modulating the host response, both directly and indirectly, with the interaction with the immune system of central importance.

\section{'Contact-dependent' mechanisms}

These mechanisms of action comprise those that necessitate the presence of MSCs at or near the sites of injury [8]. Islam and colleagues demonstrated a 'contact-dependent' 
mechanism of action whereby MSCs were shown to directly contact and transfer cellular components to lung epithelial cells [8]. Key elements of MSC-macrophage interactions may also be contact-dependent [9]. A recent study has shown the transfer of MSC extracellular vesicles to macrophages via tunnelling nanotubules [10, 11]. The capacity of MSCs to migrate or 'home' to sites of injury, a key characteristic that may affect the efficacy of contact-dependent mechanisms of action, may be enhanced for therapeutic benefit. The migratory capacity of MSCs can be modulated by factors such as culture, passage number, donor age and the dosage of MSCs [12].

\section{Paracrine mechanisms}

Mediators secreted by MSCs also mediate multiple effects. The MSC 'secretome' has been shown to mediate, at least in part, repair following ventilator-induced lung injury and to enhance bacterial killing in a number of studies [13-16]. The MSC secretome is a complex array of components, ranging from soluble secreted factors to factors encapsulated in extracellular vesicles. Extracellular vesicles range in size, composition, contents, and quantity, with different properties depending on source and method of release (due to stress, inflammation or other cues) [17]. The transfer of MSC exosomes containing miRNAs to endothelial cells have been shown to promote angiogenesis in HUVECs both in vitro and in vivo [18], and the production of hepatocyte growth factor by MSCs has been shown to be responsible for the restoration of endothelial monolayer integrity following LPS-induced permeability [19].

\section{Trans-differentiation}

While trans-differentiation is not considered a major mechanism of action, a small number of studies have demonstrated the in vivo differentiation capacity of MSCs after transplant. One such study demonstrated that MSCs engrafted and differentiated to AEC II cells in the lung, and their behaviour was influenced by the injurious environment [20]. Cells were detected up to 28 days post-transplant using PCR and histopathology.

\section{Optimising the therapeutic potential of MSCs}

Strategies to optimise MSC efficacy have the overarching aim of developing a more potent, efficient MSC therapeutic, thereby producing both a more effective therapy and/ or at a reduced dose of administered cells. A successful optimisation strategy would reduce production costs and potentially be safer for patients.

\section{Optimising culture conditions}

Following isolation of MSCs, optimal culture conditions are essential to maintain therapeutic potential. MSCs reside in hypoxic environments in vivo and exposure to normoxic conditions $(21 \%$ O2) leads to oxidant generation, premature senescence, loss of 'stemness' [21] and a reduction in proliferation capacity [22]. MSCs from older mice had an age-related decrease in receptor and cytokine expression important for migration and activation of MSCs in response to inflammation, suggesting that donor age is critical to efficacy [23, 24]. Prolonged culture and passage of MSCs leads to lower levels of HLA-DR expression than when the cells are initially cultured [25]. MSC 
cryopreservation, which is important in making larger-scale multi-centre studies feasible, and ultimately for use in the clinical setting, may reduce MSC potency and viability $[26]$.

\section{Activation of MSCs}

Strategies to 'prime' MSCs before administration aim to further enhance their therapeutic potential. These strategies range from alteration of culture conditions to exposure of MSCs to inflammatory cytokines to mimic the injury microenvironment and induce a pre-activated phenotype [27-29]. An alternative approach is the use of gene overexpression strategies to enhance MSC production of key effector proteins [30-33].

\section{Biodistribution and fate of MSCs}

MSCs mediate their effects either by direct cell-cell contact, by the secretion of mediators that exert a paracrine effect on nearby cells and tissues, and (perhaps) via in situ trans-differentiation to directly replace injured cells. Consequently, exogenously administered MSCs need to become distributed within the host such that they are either in or in very close proximity to the injury site in order to exert their effects. This issue is underlined by the fact that the quantities of molecules produced by the current administered doses of MSC are vastly less than would be administered when using other biologics (picogram vs milligram range) [34].

Altering MSC distribution patterns within the host-termed 'biodistribution'-is an important, but poorly understood, strategy by which MSC efficacy may be enhanced. In addition, prolongation of the contact time between MSCs and the injury site may also enhance the efficacy of MSCs. To date, studies carried out to assess therapeutic efficacy rarely assess the pattern and/or impact of MSC biodistribution, and likewise studies carried out to determine exogenous MSC biodistribution within the host do not assess their efficacy.

\section{MSC biodistribution: current insights}

Multiple factors affect the biodistribution of systemically administered MSCs (Fig. 1). MSCs range in size from 20 to $60 \mu \mathrm{m}$ and become physically obstructed in the microcirculation of organs, which measure $5-10 \mu \mathrm{m}$ in diameter. Systemically administered MSCs must traverse the lung vasculature, with a significant proportion of the administered MSCs becoming 'trapped' in the lung shortly after administration. MSCs can remain in the pulmonary tissues for up to $24 \mathrm{~h}$ after which they were not detected [35]. This is a significant impediment to therapeutic efficacy for MSCs administered for systemic conditions, given the need for MSCs to be in close proximity to the site of injury. Several studies have examined the use of local administration (discussed below) or other methods to bypass the pulmonary capillary bed such as vasodilators [36] or intraarterial delivery [37]. However, systemic administration is a more desirable, less invasive method for treatment of organs such as the heart and brain, and the ease of access and proof of efficacy in several pre-clinical MSC-treated models make it the most likely route to be used in the majority of studies.

Nystedt and colleagues have also demonstrated a role for cellular interactions mediating MSC retention in the lungs [23]. They reported that umbilical cord-derived MSCs 


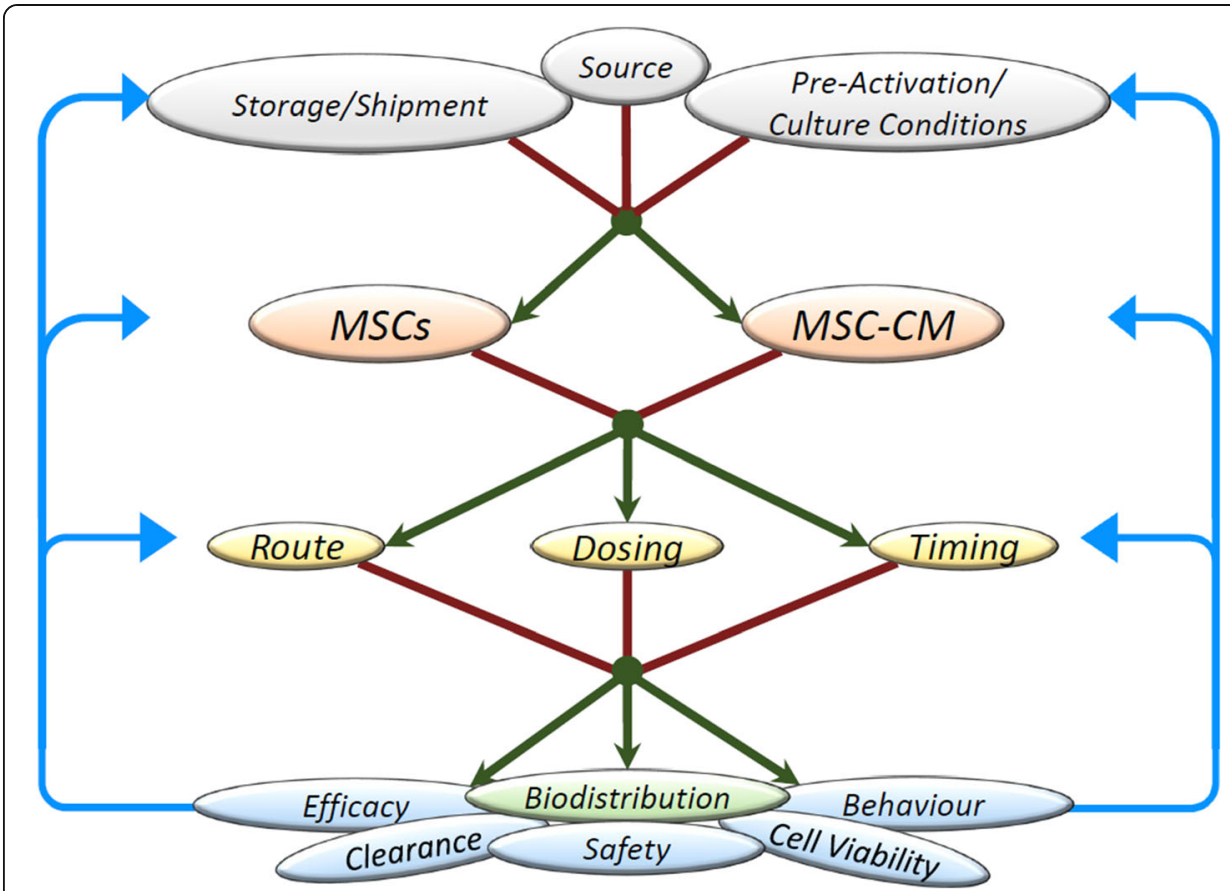

Fig. 1 Schematic representation of the factors which influence cell biodistribution in vivo. The source of MSCs (mainly adipose, cord or marrow), culture conditions, pre-activation strategies and the method of storage before administration influences the quantity and quality of MSCs and conditioned media (MSC$\mathrm{CM}$ ) produced. The decision to use either the MSCs themselves or MSC-CM, as well as considering the condition to be treated, will influence the chosen route, dosage and timing of administration which will in turn influence the biodistribution pattern of the cells or cell products. Biodistribution data will furnish knowledge of the safety, efficacy, viability, behaviour and clearance rate which will feedback to the optimal source, culture, storage, route, dosage and timing strategies

had a faster lung clearance rate than bone marrow-derived MSCs (BM-MSCs). In addition, the surface adhesion marker profile differed between the cell types, and with increasing BM-MSC donor age. Cells which were trapped in the lungs after administration were shown by histological examination to be localised to the endothelium with movement to the lung stroma observed at $24 \mathrm{~h} \mathrm{[23].} \mathrm{Other} \mathrm{studies} \mathrm{have} \mathrm{ob-}$ served intravascular rolling and adhesion of MSCs involving the adhesion molecules VCAM-1/VLA-4 and P-selectin after intraarterial injection [38]. Intravital microscopy experiments have demonstrated the transmigration of MSCs between and through endothelial cells in the dermal microcirculation in a similar but slower process than leukocytes [39]. MSCs have been shown to migrate to the liver, kidney and/or spleen after clearance from the lung; however, detection methods that determined this generally did not ascertain if the signal obtained was from viable, intact MSCs, from cell fragments or free label. The type and location of tissue injury may alter MSC distribution. Systemically delivered MSC to models of myocardial infarction was shown to differentially distribute between healthy and injury models with increased numbers of radiolabelled cells detected in the infarcted heart after administration [40].

In summary, a better understanding of patterns of biodistribution and of the fate of MSCs will uncover strategies to increase the distribution and/or persistence of MSC at 
the sites of injury, potentially increasing their therapeutic potential for multiple disorders, including critical illnesses such as ARDS and sepsis.

\section{MSC fate: current insights}

Intravenously administered MSCs first accumulate in the lung vasculature, move to other major organs such as the liver and kidneys and after a variable but short period ( $24 \mathrm{~h}$ to 14 days) are no longer detectable in the body. The ultimate fate of exogenously administered MSCs remains unclear. While reports of MSC engraftment and differentiation exist, the numbers detected are vastly lower than the administered number of cells. There are further reports of MSCs being phagocytosed by the host immune system as a possible mechanism of their clearance [41]. Another potential method of MSC clearance is that MSCs under stress may undergo apoptosis and break up into micro-particles. This mechanism first suggested following in vitro experiments by Bian et al. [42]. These microparticles could then be redistributed around the body to be either phagocytosed or filtered by the kidneys for excretion.

The host immune system plays a role in MSC clearance. While traditionally thought to be 'immune-privileged', it appears that MSCs are better characterised as 'immune-evasive' [43]. Studies demonstrate the production of antibodies against MSC transplant and rejection of same [44-46] albeit in a slower manner than rejection of other allogenic cell types such as fibroblasts [43]. The host can acquire immunity to MSCs after multiple dosing by an increase in the percentage of memory $\mathrm{T}$ cells after administration [47]. In this regard, in mice that are T and B cell, or NK cell deficient, and in irradiated mice, MSCs were shown to persist longer than in immunocompetent mice [48].

Cryopreservation of MSC, which facilitates storage for clinical use, may increase MSC clearance in vivo. MSCs which were thawed and administered via intramuscular injection were cleared within 3 days as compared to those grown in culture overnight which persisted for up to 3 months [49]. These findings support a previous study demonstrating cytoskeletal disruption and differences in biodistribution between fresh and frozen cells [50].

Perhaps most intriguingly, in terms of MSC fate, is the recent demonstration by Galleu and colleagues that MSC apoptosis after administration may be necessary for therapeutic benefit [51]. Patients with graft-vs-host disease that had a more cytotoxic response to MSCs also responded better to the MSC therapy.

In summary, our understanding of the fate of exogenously administered MSCs, a potentially central issue in regard to maximising the efficacy of MSCs, remains a significant knowledge gap.

\section{Methods of imaging MSC distribution and fate}

The ideal imaging technique would incorporate a label/probe which is non-toxic, that does not alter the cell morphology or phenotype, and is reliable in terms of labelling method, signal strength, and is long-lived in vivo (Fig. 2). A desirable quality would also be that the label/probe would not be detectable upon administered cell death. The detection method should be non-invasive, not cause harm to the subject, be rapid and sensitive, and be capable of repeated use. A further desirable quality would be that it could render 3D images and display anatomical structures as well as relaying real-time 

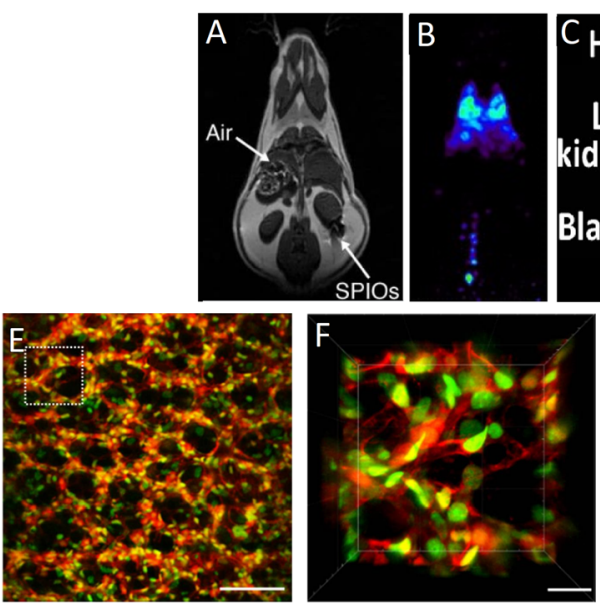

Fig. 2 A comparison of the imaging techniques for analysing biodistribution. a MRI scan revealing detailed anatomical structure but poor distinction between air-tissue interface and SPIO radiolabel [123]. b PET detection of IV administered radiolabelled MSCs showing good resolution with no anatomical structure [124]. c Gamma camera acquisition of radiolabelled IV administered cells demonstrating lower resolution than PET and no anatomical structure [125]. d BLI detection of luciferase reporter-labelled MSCs administered IV demonstrating a lower sensitivity than PET/SPECT and external anatomical structure alluding to in vivo cell location [126]. e, $\mathbf{f}$ Intravital microscopy imaging of live tissues demonstrating the specificity of labelling at the cellular level (pulmonary tissue; cytoplasm = red, nuclei = green) [127] g GFP-labelled MSCs detected in lung tissue sections (green) with cell nuclei clearly visible (blue) [128]. $\mathbf{h}$ The use of the CryoViz ${ }^{\circledR}$ system offers the 3D reconstruction of histological sections containing MSCs labelled using Q dots [71]

events in cell tracking. For observing MSC interactions in vivo, sensitivity at a micron range would be essential.

Current techniques fulfil the majority of these properties separately (Table 1). However the main obstacle to their routine clinical use is the use of probes, labels, and detection methods which may compromise either the administered cell's function or the host themselves. Many of the studied detection methods are not sensitive enough without being invasive or having the need for post-mortem samples. Previously, methods of cell tracking in vivo were limited to post-mortem analysis of excised and sectioned tissues, limiting time points and requiring sacrifice of multiple animals. Advances in whole body, vital in vivo imaging have led to the use of systems such as MRI, PET and SPECT and specialised small animal systems such as in vivo imaging systems (IVIS) using near-infrared (NIR). The following paragraphs discuss imaging/tracking methodologies used, their principles, suitability, limitations and possible translation to clinical situations.

\section{Labelling of MSCs}

The purpose of cell labelling is to distinguish administered cells from host tissue and to easily identify their movement and behaviour in vivo. Ideally, cells should be easily detectable to a high-resolution over long periods, be unchanged from their naïve phenotypical and morphological state, be non-toxic and be located using a minimally invasive method. There are several methods of cell labelling, and developments in recent years have allowed higher resolution, more accurate and long-term analyses of their journey in vivo. 
Table 1 A comparison of methods used to analyse MSC biodistribution patterns in animal models

\begin{tabular}{|c|c|c|c|c|c|}
\hline Method & $\begin{array}{l}\text { Used } \\
\text { clinically }\end{array}$ & $\begin{array}{l}\text { Terminal/ } \\
\text { post-mortem }\end{array}$ & $\begin{array}{l}\text { Single-cell } \\
\text { resolution }\end{array}$ & Benefits & Limitations \\
\hline$\overline{\mathrm{MRI} / \mathrm{CT}}$ & $\checkmark$ & $x$ & $x$ & $\begin{array}{l}\text { Good anatomical structure, } \\
\text { unlimited depth, can be } \\
\text { used with PET/SPECT }\end{array}$ & $\begin{array}{l}\text { Poor distinction between } \\
\text { probe and air, possibility of } \\
\text { free probe, expensive, low } \\
\text { sensitivity }\end{array}$ \\
\hline PET & $\checkmark$ & $x$ & $x$ & $\begin{array}{l}\text { High resolution, unlimited } \\
\text { depth }\end{array}$ & $\begin{array}{l}\text { Expensive, shorter half-life of } \\
\text { probe, no anatomical data, } \\
\text { radiation exposure }\end{array}$ \\
\hline SPECT & $\checkmark$ & $x$ & $x$ & $\begin{array}{l}\text { Inexpensive, longer-lived } \\
\text { probe, unlimited depth }\end{array}$ & $\begin{array}{l}\text { Low resolution, no anatomical } \\
\text { data, radiation exposure }\end{array}$ \\
\hline BLI & $x$ & $x$ & $\checkmark$ & $\begin{array}{l}\text { Can distinguish live/dead } \\
\text { cells, inexpensive, high } \\
\text { sensitivity }\end{array}$ & $\begin{array}{l}\text { Poor tissue penetration, single- } \\
\text { cell distinction not possible }\end{array}$ \\
\hline PCR & $\checkmark$ & $\checkmark$ & $x$ & $\begin{array}{l}\text { Highly specific, widely } \\
\text { available }\end{array}$ & $\begin{array}{l}\text { Limited observational area, } \\
\text { cannot distinguish live/dead, } \\
\text { detects genetic material only }\end{array}$ \\
\hline Histology & $\checkmark$ & $\checkmark$ & $\checkmark$ & $\begin{array}{l}\text { Accessible technique, high- } \\
\text { quality images obtained, } \\
\text { can demonstrate cell } \\
\text { viability, interactions, } \\
\text { molecular changes }\end{array}$ & $\begin{array}{l}\text { Cannot account for changes } \\
\text { during processing, limited } \\
\text { observational area. Requires } \\
\text { biopsy/post-mortem samples }\end{array}$ \\
\hline $\begin{array}{l}\text { Intravital } \\
\text { microscopy }\end{array}$ & $x$ & $\checkmark$ & $\checkmark$ & $\begin{array}{l}\text { Highly sensitive, allows } \\
\text { observation at micrometre } \\
\text { scale, phenotypical and } \\
\text { morphological cell } \\
\text { changes observable }\end{array}$ & $\begin{array}{l}\text { Highly invasive, requires } \\
\text { specialised techniques/ } \\
\text { equipment, limited } \\
\text { observational area }\end{array}$ \\
\hline
\end{tabular}

\section{Fluorescent and bioluminescent labelling}

MSCs can be fluorescently labelled using fluorophores linked to a specific molecule in/ on the target cells or transduced with a bioluminescent or fluorescent protein reporter gene. These labelling methods are well characterised and commercially available requiring an ex vivo preparation (transduction or transfection) of the cells before administration, allowing for characterisation of phenotypical and morphological properties and toxicity beforehand. Detection of fluorescence labels after administration requires the application of an excitation light source at specific wavelengths to activate the emission of fluorescent light from a fluorophore. Bioluminescent labelling generally requires the administration of probes (substrates) which are catalysed by the intracellular enzyme (generally luciferin or coelenterazine produced by transduced reporter genes) to produce a bioluminescence signal [52]. Difficulties occur due to the limitations arising from the ability to detect fluorescent/bioluminescent cells in deeper tissues via whole body imaging. Developments in microscopy techniques such as multiphoton excitation which allows high-resolution image acquisitions in thicker tissue sections than conventional fluorescence microscopy [53] have overcome this challenge to some extent. Near-infrared (NIR) imaging is emerging as a promising in vivo detection method. With the development of safe and effective contrast agents and the use of fluorescent nanoprobes, NIR provides the ability to penetrate into the deeper tissues [54-56].

\section{Labelling using radionucleotides}

The use of radionucleotides is a currently approved method in clinical use allowing for a non-invasive detection of labelled cells and tissues [52]. Cells can be exposed to 
labelling agents which are extracellular-binding the cell membrane via linking to lipophilic long chain esters, such as ${ }^{64} \mathrm{Cu}$-DOTA-HB, or are intracellular following passive or transporter uptake such as ${ }^{111} \mathrm{In}$-oxine or ${ }^{18} \mathrm{~F}$-FDG, and are detected by SPECT or PET imaging in vivo [57]. An indirect method of radionucleotide labelling involves the use of reporter gene constructs in MSCs which produce proteins with a high affinity for radionucleotides which can be injected separately at multiple time-points [58]. This overcomes some of the shortfalls of this method due to the generally short half-life of the particles. SPECT and PET are often used in conjunction with MRI or CT, which uses superparamagnetic iron oxide (SPIO)- or AuNPS-based contrast agents to confirm the anatomical location of labelled cells using image overlay. Indeed, SPIO or AuNPS can be directly used as intracellular MSC labels as they are taken up by endocytosis ex vivo [57], although the sensitivity of these detection methods can be poor [58].

\section{Benefits, limitations and insights}

The benefits of using fluorescent labels are that the effects on the cells are well characterised, multiple coloured dyes can be used and easily distinguished using different excitation/emission wavelengths, and in certain cases it will allow for the distinction between dead and viable cells in vivo. The use of reporter genes can also demonstrate the expression of certain transgenes in response to the in vivo environment giving further insight to the in vivo behaviour of MSCs $[59,60]$. There is a concern in the use of DNA-binding dyes such as DAPI and the introduction of reporter constructs using viral vectors which may have some downstream immunogenicity or mutagenesis potential, making them unsuitable for clinical use [61]. Methods of detecting fluorescence often require ex vivo analysis of tissues or terminal in vivo techniques eliminating the possibility of reusing animals at different time-points. This can be overcome by using whole body imaging techniques such as PET and SPECT. The use of radiolabelling methods such as ${ }^{111}$ In-oxine has been reported as a suitable, safe method of MSC tracking in human subjects; however, tracer leakage has been reported from MSCs [62]. It has been also reported that prolonged storage of radiolabelled ( ${ }^{111}$ In-oxine) leukocytes leads to diminished chemotaxis, high spontaneous release of radionucleotide and impairs cellular function [63, 64]. However, the majority of radioactive probes used in recent pre-clinical studies are FDA- and EMA-approved for clinical use [58]. Limitations to the use of radionucleotide/contrast agent labels include a short half-life and 'bleaching', difficulties in tracking cells in real-time and over longer periods in the same animals, unclear distinctions between labelled cells, free label and phagocytes containing cell particles, and depending on the method of labelling, there may be an impact on cell viability. Reporter construct labelling, which produces a high-affinity protein, can overcome the issue of radio label longevity by persistent gene expression for the duration of the cell life-span [58].

\section{Real-time PCR}

\section{Principle}

Real-time or quantitative PCR ( $\mathrm{qPCR}$ ) has been used for in vivo tracking due to the ability to detect on a genomic level the relative amounts of integrated particles based on their gene expression. In a tissue sample, it would therefore be advantageous if one 
could discriminate between host and administered cells in terms of MSC administration. To do so using qPCR, it is necessary to identify a target for quantification. Researchers have used various techniques, the most common being to transduce or transfect a reporter gene such as luciferase or GFP into the cells before administration to allow for definitive identification by gene expression. Other methods involve the use of male donor cells (XY) into a female recipient (XX) and subsequent detection of the $\mathrm{Y}$ chromosome, or human cells into other species and subsequent detection of human-specific genes.

\section{Studies performed}

Devine and colleagues utilised GFP-transduced MSCs in their biodistribution study in immunocompromised baboon models. Analysis of distribution was performed by real-time PCR analysis of eGFP cDNA content in various tissues between 9 and 21 months post-infusion [65]. Development of qPCR assays for the detection of male, murine and human MSCs after infusion to mice allowed the detection of DNA from MSCs up to 300 days post-implant in the central nervous system of neonatal and adult mice [66] demonstrating the benefits of qPCR as a detection method over extended periods of time. Post-mortem samples from 15 patients who received MSCs were examined by PCR for engraftment in various tissues [67]. In these patients, MSC DNA was detected in samples of 8 of the patients with an overall pattern of limited engraftment, without ectopic tissue formation. Furthermore, MSC treatment response did not correlate with engraftment rates.

\section{Benefits, limitations and insights}

Real-time PCR as a method of detection of MSCs requires the harvest of tissues for RNA isolation. Therefore, a limitation of this method is that animals need to be sacrificed at various time-points for a complete observation of distribution over time. The potential for biopsies to render a true representation of the biodistribution pattern, given that only a small segment of the organ can be analysed, is unclear. This approach does not distinguish between MSC cellular contents delivered by intact cells or from fragments or vesicles from MSCs. However, this technique may demonstrate that the contents of administered MSCs travel beyond the lungs and engraft in other organs over long periods of time [65]. In other words, qPCR will not distinguish between viable, intact MSCs and free or integrated target sequences. The benefits of using qPCR as a detection method are that it is highly specific and depending on the target gene chosen (e.g. sex-linked chromosome gene mismatches) and there may be no need to label the cells before administration. The high specificity of this method means that only a small sample of tissue is required for detection, such as patient biopsy samples $[68,69]$.

\section{Ex vivo imaging of tissues \\ Principle}

In this approach, following in vivo administration of fluorescently labelled MSCs, the tissues of interest are excised post-mortem, fixed and sectioned for imaging using fluorescence microscopy. This method has been used successfully in mouse models of 
corneal injury who received GFP- or Q-dot-labelled MSCs [70] using fluorescence microscopy of fixed and sectioned specimens. Using methods such as the $\mathrm{CryoViz}^{\circ}$ imaging system a 3D reconstruction of whole organs/small animals can be amalgamated [71]. The CryoViz ${ }^{\circ}$ system is used to create serial sections of whole organs or even whole small animals, acquire images of each section using brightfield and confocal microscopy, and reconstruct the whole organ/animal as a 3D output. Flow cytometry has also been used to detect MSCs in the peripheral blood [70] and tissue homogenates [13] at various time points following injury.

\section{Studies performed}

Fluorescent protein labelling or reporter gene transduction followed by histology and/or immunohistochemistry are the most common procedures in these studies [72, 73]. Studies have also analysed tissues ex vivo using fluorescent antibodies against the administered human cells in rat models of brain injury [74]. Fluorescently labelled MSCs were injected into models of corneal injury and subsequently detected locally using epifluorescence microscopy in ex vivo corneas, and in the circulation by flow cytometry [70]. The study found that increased levels of substance P and SDF-1 occurred at the injury site and suggested their responsibility for increased MSC homing to the injury. The researchers also found that MSCs persisted in the cornea up to 50 days post-injection. Using the CryoViz system, Schmuck and colleagues performed a biodistribution study after intrajugular administration to a rat model of lung injury [71]. Between $60 \mathrm{~min}$ and $240 \mathrm{~min}$ post-administration over $99 \%$ of the detected cells were found in the lungs, liver, and spleen-the liver was the primary site of accumulation in this study.

\section{Benefits, limitations and insights}

The ex vivo imaging of tissues requires the sacrifice of animals at various time points and limits the analyses to the tissues excised and the area processed for imaging. The use of detection methods such as $\mathrm{CryoViz}^{\circ}$ reduces the workload of isolation and processing and can be performed on whole organs and indeed whole mice to give an overall perspective of cell biodistribution. The chosen label will have an impact on the readout of the experiment. For example, DAPI-labelled cells administered to mouse models of myocardial infarction were detected 7 days after infusion in infarcted areas of the heart [40] by observation of tissue sections post-mortem. DAPI staining provides information on the presence of the MSC nuclear material, but not in the size, intactness or morphology of the MSC.

Flow cytometry can be performed on blood samples to detect circulating MSCs or using tissue homogenates to detect tissue-resident cells. Again, this generally requires post-mortem analyses and a requirement for many animals at different time points. Flow cytometry analyses will allow for quantification of cell number per gram of tissue and can discriminate live and dead cells [75]. Further analyses of the cells can be performed using FACS analysis alluding to their phenotypical changes in vivo.

\section{In vivo imaging systems}

\section{Intravital microscopy}

Intravital microscopy (IVM) involves the use of fluorescent microscopy directly over the area of interest in live animal models, usually of the visible vasculature close to the 
surface of the tissue/organ under study. The passage of fluorescently labelled molecules and cells can then be recorded in real time allowing for the calculation of particle kinetics in a live model. The use of microscopy and the advances in cell-labelling techniques mean that observation on a micron scale is possible. This allows visualisation of interactions and behaviours of the MSCs such as rolling and adhesion, transmigration, velocity within blood vessels and interactions with other cell types that would not be possible using other techniques.

Studies performed IVM has been used to study a range of in vivo mechanisms including glomerular filtration in the kidneys [76], pancreatic blood flow [77], cancer cell motility [78], and immune cell trafficking (reviewed in [79]). IVM can be used to image fluorescently labelled cells in vivo by the application of a fluorescent microscope lens directly to the area of interest [80-83]. This allows the real-time visualisation of the transit of systemically and locally applied fluorescent cells within the tissue and vasculature and observation over a limited period of time and their behaviour and interactions in live tissues. The transit of MSCs in a model of dermal inflammation [39] or adhesion molecule p-selectin knockout mice [38] was examined by visualisation of the vasculature in the ear. These studies allowed the visualisation in real time of the interactions of MSCs with the vasculature and the effects of resident blood cells. Intravital microscopy has also been used to observe MSCs 'in transit' in the vasculature of cremaster muscles allowing visualisation of MSC longevity, velocity, and deformability [84].

Benefits, limitations and insights The ability to visualise both the transit and interaction of MSCs in a live animal model provides significant insights into mechanisms of action. IVM allows the visualisation of individual cells and even molecular interactions in vivo, a level of magnification that cannot be achieved currently in most other methods used. IVM is mainly constrained by the range of tissue penetration which is limited to the first $100 \mu \mathrm{m}$ below the surface [85] but can be extended up to $1 \mathrm{~mm}$ (depending on tissue imaged) using multiphoton microscopy [79]. The observational area during the procedure is also quite small with generally a window of approximately $10 \mathrm{~mm}$ available over the site of interest. Depending on the area of interest, the invasiveness of the surgery, and the prolonged period under anaesthesia, the animal generally has to be sacrificed at the end of the procedure. This may only allow a constrained period of observation and multiple animals would be required for longer studies. However, the tissues from these animals can be retained for subsequent histological analyses.

\section{Whole body imaging}

Principle

Whole body imaging can be a challenging technique whereby one needs to consider a range of factors. In the context of tracking the biodistribution of individual cells, careful consideration needs to be given to the probe used to distinguish the administered cells from other cells and tissues of the body. One immediate difficulty is apparent-the need for a probe which will be strong enough for detection through the skin (and fur in pre-clinical models) and a detection method which will give the precise anatomical location and a sensitivity to detect individual cells. The use of radiolabelled cells is a 
popular choice for whole body imaging due to both their routine use in the clinic and the strength of the signal produced. Whole body tomography is a useful tool that allows for real-time tracking of radiolabelled cells at multiple time-points without tissue biopsy or animal sacrifice or injury. Positron emission or single photon emission computed tomography (PET or SPECT) are the two main methods of detection of radiolabelled cells and can be used in combination with X-ray CT or MRI to show the exact location in vivo [58].

Dynamic near-infrared fluorescence (DNIF) has been investigated for fluorescent probe detection in human subjects with promising results [86]. Using an IV bolus of indocyanine green, DNIF could detect the passage of the administered probe in a whole body image rendering images to show the real-time transit in the body. Luminescence has been generally considered a poor candidate for whole body imaging due to its weak signal and pseudo-colour-generated images [87] and the need for circulating luciferin [88]. NIR persistent luminescence nanoparticles have been developed recently [89] and are considered a promising candidate for whole body bioimaging due to the persistence of luminescence which can last for hours to days after excitation [90]. The development of the in vivo imaging system (IVIS ${ }^{\circ}$ ) in recent years has allowed deeper penetration of tissues for the detection of bioluminescence [75].

\section{Studies performed}

Earlier studies of administered bone marrow MSCs used techniques such as radiolabelled cells administered intravenously (IV) or intraarticularly (IA) followed by whole body computed tomography (CT) scans [37, 91, 92]. The majority of these studies concluded that systemic infusion of MSCs resulted in an initial accumulation in the lung $[35,93]$. One of these studies noted that the use of vasodilators encouraged MSC clearance from the lungs indicating the role of cell size versus capillary diameter in lung accumulation [93]. A more recent study has examined MSC distribution in an uninjured porcine model using radiolabelled cells administered either IV or IA [94]. CT scans revealed the accumulation of cells in the lungs, kidneys, liver, spleen and vertebrae in descending order. IA administration resulted in a reduced lung accumulation due to a bypass of the pulmonary capillary bed. Neural MSCs were transfected with ${ }^{111}$ In labelled silica nanoparticles and administered via intracranial or intracardiac injection to mouse models of glioblastoma [95]. Mice were imaged using SPECT/CT demonstrating that labelled neural MSCs migrated toward the tumour site after systemic administration. In patients with advanced liver cirrhosis, radiolabelled MSCs were administered systemically and patients subjected to planar whole body image acquisitions at various time-points thereafter [96]. The study demonstrated MSC accumulation initially in the lungs, followed by increases in the spleen and liver up to 10 days post-administration. MSC labelled with near-infrared fluorescent nanoparticles were administered to mouse models of Chagas disease and visualised using an IVIS ${ }^{\circ}$ in combination with PET scans [97]. More recently, Cao and colleagues performed a study using bioluminescence and the IVIS system both in vivo and ex vivo demonstrating migration of the MSCs in healthy animals to the lungs, kidneys and lower back and complete MSC clearance from the animal by day 14. [75]. Bioluminescence has also been used in animals subjected to colitis injury and intraperitoneal (IP) administration of MSCs [98] 
demonstrating that distribution of MSCs was largely dependent on the route of administration rather than the inflammatory environment. Further analyses by this group deduced that MSC presence at the site of inflammation was necessary for therapeutic effect.

\section{Benefits, limitations and insights}

Use of MRI or X-ray CT scans to detect labelled cells harbours little to no risk to the subject. However, the effect of multiple scans is not known but assumed to be low risk $[99,100]$. Although PET and SPECT imaging are high sensitivity imaging modalities which can detect radioisotopes on a picomolar scale [58], these techniques do not have a single-cell resolution. Isotopes used in PET scanning have a shorter half-life than those used in SPECT scanning (up to 4 days vs up to 8 days). This can be overcome by using a combination method with a reporter gene construct as mentioned previously [58]. The key limitation to PET/SPECT/MRI methods of detection is that there can be no distinction between viable, intact cells and free or phagocyte-engulfed label. PET imaging allows detection at a higher sensitivity compared to MRI but a lower spatial resolution and no anatomical data to pinpoint location with both methods resulting in lower resolution imaging at cellular and sub-cellular levels [56].

\section{Strategies to alter MSC biodistribution and fate}

\section{Decreasing MSC lung trapping}

The co-administration of the vasodilator sodium nitroprusside can enhance MSC passage through lung capillaries [101]. Inhibition of CD49d may also facilitate passage through the lung, while administration of the MSCs in divided doses may also aid trans-pulmonary passage [102]. Intrahepatic arterial MSC injection in a mouse enabled bypass of the lung vasculature, with up to four times more cells accumulating in the liver compared to standard IV injection [75]. However, a previous study reported the formation of pulmonary emboli after intraarterial administration of MSCs in mice [103] suggesting the need for care with this route.

\section{Local delivery of MSCs}

Local MSC delivery may result in the accumulation and persistence of substantially higher numbers of MSCs at the site of injury. Intracoronary injection resulted in a significant retention of cells in the cardiac tissues compared to peripheral vein administration [104]. However, intracoronary delivery may cause decreased coronary blood flow [105], and even acute MI [106], suggesting the need for caution. Radioactively labelled MSCs were injected either IV or into the left ventricular cavity of rats subjected to myocardial infarction. The intraventricular administration of MSCs was demonstrated to overcome the accumulation of MSCs in the lung seen after IV administration [91].

Iron oxide nanoparticle-containing MSCs were administered either IV or directly into the corpus callosum of healthy and LPS-injured rats and detected by MRI up to 30 days post-administration [107]. Locally administered cells in healthy animals remained localised to the administration site and migrated toward the lesion in injured animals after both IV and IC administration. In healthy pigs, IA administration of radiolabelled 
MSCs resulted in a lower accumulation in the lungs and a higher MSC content in the liver after $8 \mathrm{~h}$ as demonstrated by SPECT/CT imaging [94].

An interesting study by Chen and colleagues [108] examined the differential migration properties of MSCs after injection into the bone marrow or caudal vein of mice with a liver injury. Using PCR, flow cytometry and cryosectioning, it was determined that liver injury mobilised the transplanted MSCs from the marrow toward the liver, a mechanism dependent on cytokine release from the injury site. A comparison of delivery routes was performed using IV, IP, SC and IM in healthy animal models, and detection of these cells was carried out using bioluminescence detection [49]. IV MSCs were undetectable within days, IP and SC persisted for up to 4 weeks, but IM injection resulted in MSC detection over 5 months.

\section{Production of smaller MSCs}

In contrast, culture conditions that result in the production of smaller MSCs may significantly alter biodistribution by reducing MSC and size obstruction trapping in capillary beds of the lung. Ge and colleagues [109] have compared different culture methods: 3D hanging drop vs 2D monolayer culture and demonstrated that MSC size was much more homogeneous and smaller in 3D culture with an average cell diameter of $12.6 \mu \mathrm{m}$ vs $26.5 \mu \mathrm{m}$ from the monolayers. Gene overexpression approaches may facilitate targeting of MSCs to specific targets. It has also been shown that the endothelial-binding molecules on the surface of MSCs can be altered ex vivo affecting their binding ability after administration [110-113].

\section{Enhancing MSC migration}

Enhancing the migration potential of MSCs in vivo may increase their presence at the site of injury. Overexpressing receptors such as CXCR4 which mediate migration of MSCs could facilitate the enhancement of the cells in vivo as demonstrated by Yang and colleagues [114]. The CXCR4 receptor expression is reduced in cultured MSCs over time [115] and by overexpression of CXCR4, Yang and colleagues demonstrated an enhanced migration potential in mouse models of ALI 2 weeks after transplant [114]. In a study to compare MSC migration capacity toward 16 different growth factors and chemokines, it was shown that untreated MSCs migrate differentially than MSCs pre-treated with TNF- $\alpha$ which have a greater migration capacity [116].

\section{Increasing MSC longevity}

This strategy is based on the contention that increased MSC longevity and/or retention at the injury site may enhance effectiveness. Melatonin has been examined as a potential treatment to induce longevity and 'stemness' of MSCs [117] and the use of these pre-treated MSCs in vivo increased their survival and reduced apoptosis in cerebral ischemia [118]. Transducing MSCs with lentiviral vectors to induce COX1 overexpression enhanced the therapeutic efficacy of the cells in pulmonary hypertension models and also increased their longevity to at least 21 days in the lung tissue [119]. 


\section{Altering MSC cell surface markers}

The cell surface molecules on MSCs appear to play a role in the clearance of administered MSCs from the lung [23]. Umbilical cord MSCs demonstrate a different profile of cell surface markers compared to bone marrow-derived MSCs, and this was implicated in enhanced lung clearance of UC-MSCs. Altering cell surface marker expression on MSCs may be used to decrease-or increase-retention time in the lung, and thereby impact MSC function in vivo.

\section{Summary and conclusions}

The use of MSCs as a therapeutic is a promising, effective strategy in numerous disease and injury states in pre-clinical models. As of 2016, there were 493 MSC-based clinical trials completed or ongoing [120]. Unfortunately, limitations in our understanding of the biodistribution and fate of therapeutically administered MSCs within the body constitute a significant impediment to successful clinical translation of MSCs. The FDA guidelines [121] and the European Medicines Agency [122] guidelines for drug development both require the generation of pre-clinical data on pharmacodynamics and biodistribution before product approval.

While understanding biodistribution and fate in patients is clearly more challenging for a cellular therapy than for a standard pharmacologic, recent advances in imaging techniques now offer the possibility to more systematically develop our knowledge of these issues. A clear characterisation of the in vivo kinetics of MSC therapeutics would provide insight to important unknowns such as the optimal route of administration, the optimal dosage size and regimen, the potential for altering the MSC microenvironment ex vivo to modulate their in vivo kinetics, and indeed whether or not MSCs need to be present at the site of injury.

In summary, a better understanding of patterns of biodistribution and of the fate of MSCs will not only provide much-needed safety data, but will also uncover strategies to increase the distribution and/or persistence of MSC at the sites of injury, potentially increasing their therapeutic potential for multiple disorders in the clinic.

\footnotetext{
Abbreviations

AEC: Airway epithelial cell; ARDS: Acute respiratory distress syndrome; BM: Bone marrow; CDNA: Complementary DNA; COX1: Cyclooxygenase-1; CXCR4: CXC chemokine receptor 4; DNIF: Dynamic near-infrared fluorescence; eGFP: Enhanced green fluorescent protein; EMA: European Medicines Agency; FDA: Food and Drug Administration; HLA: Human leukocyte antigen; IA: Intraarticularly; IP: Intraperitoneal; IV: Intravenously; IVIS: In vivo imaging systems; IVM: Intravital microscopy; MRI: Magnetic resonance imaging; MSC: Mesenchymal stromal cell; NIR: Near-infrared; PCR: Polymerase chain reaction; PET: Positron emission technology; SC: Subcutaneous; SPECT: Single photon emission computed tomography; TNF-a: Tumour necrosis factor alpha; UC: Umbilical cord; VCAM: Vascular cell adhesion molecule

Acknowledgements

Not Applicable

Funding

John Laffey and Claire Masterson are funded by an SFI Future Research Leaders grant from Science Foundation Ireland (16/FRL/3845). Publication of this article was sponsored by a grant from the INSPIRES III Conference.
}

Availability of data and materials

Not Applicable

About this supplement

This article has been published as part of the supplement Intensive Care Medicine Experimental Volume 7 Supplement 1 2019: Proceedings from the Third International Symposium on Acute Pulmonary Injury and Translational Research (INSPIRES III). The full contents of the supplement are available at https://icm-experimental.springeropen.com/articles/ supplements/volume-7-supplement-1. 
Authors' contributions

$\mathrm{CM}$ and $\mathrm{J} \mathrm{L}$ created the first draft of the manuscript. All authors revised the manuscript and approved the final version.

\section{Ethics approval and consent to participate}

Not Applicable

\section{Consent for publication}

Not Applicable

\section{Competing interests}

The authors declare that they have no competing interests.

\section{Publisher's Note}

Springer Nature remains neutral with regard to jurisdictional claims in published maps and institutional affiliations.

\section{Author details}

${ }^{1}$ Regenerative Medicine Institute (REMEDI) at CÚRAM Centre for Research in Medical Devices, Biomedical Sciences Building, National University of Ireland Galway, Galway, Ireland. ${ }^{2}$ School of Medicine, College of Medicine, Nursing and Health Sciences, National University of Ireland Galway, Galway, Ireland. ${ }^{3}$ Department of Anaesthesia and Critical Care, Royal College of Surgeons in Ireland Education and Research Centre Smurfit Building, Beaumont Hospital, Dublin 9, Ireland. ${ }^{4}$ Department of Anaesthesia and Intensive Care Medicine, Galway University Hospitals, SAOLTA Hospital Group, Galway, Ireland.

Received: 19 February 2019 Accepted: 7 March 2019

Published: 25 July 2019

\section{References}

1. Friedenstein AJ, Chailakhjan RK, Lalykina KS (1970) The development of fibroblast colonies in monolayer cultures of Guinea-pig bone marrow and spleen cells. Cell Tissue Kinetics 3:393-403

2. Friedenstein AJ, Gorskaja JF, Kulagina NN (1976) Fibroblast precursors in normal and irradiated mouse hematopoietic organs. Exp Hematol 4:267-274

3. Dominici M, Le Blanc K, Mueller I, Slaper-Cortenbach I, Marini F, Krause D, Deans R, Keating A, Prockop D, Horwitz E (2006) Minimal criteria for defining multipotent mesenchymal stromal cells. The International Society for Cellular Therapy position statement. Cytotherapy 8:315-317

4. Pittenger MF, Mackay AM, Beck SC, Jaiswal RK, Douglas R, Mosca JD, Moorman MA, Simonetti DW, Craig S, Marshak DR (1999) Multilineage potential of adult human mesenchymal stem cells. Science 284:143-147

5. Galipeau J, Sensebe L (2018) Mesenchymal stromal cells: clinical challenges and therapeutic opportunities. Cell Stem Cell 22:824-833

6. McIntyre LA, Stewart DJ, Mei SHJ, Courtman D, Watpool I, Granton J, Marshall J, Dos Santos C, Walley KR, Winston BW, Schlosser K, Fergusson DA (2018) Canadian critical care trials G, the Canadian critical care translational biology G. Cellular immunotherapy for septic shock (CISS): a phase I clinical trial. Am J Respir Crit Care Med 197:337-347

7. Wilson JG, Liu KD, Zhuo H, Caballero L, McMillan M, Fang X, Cosgrove K, Vojnik R, Calfee CS, Lee J, Rogers AJ, Levitt J, Wiener-Kronish J, Bajwa EK, Leavitt A, McKenna D, Thompson BT, Matthay MA (2015) Mesenchymal stem (stromal) cells for treatment of ARDS: a phase 1 clinical trial. Lancet Respir Med 3:24-32

8. Islam MN, Das SR, Emin MT, Wei M, Sun L, Westphalen K, Rowlands DJ, Quadri SK, Bhattacharya S, Bhattacharya J (2012) Mitochondrial transfer from bone-marrow-derived stromal cells to pulmonary alveoli protects against acute lung injury. Nat Med 18:759-765

9. Nemeth K, Keane-Myers A, Brown JM, Metcalfe DD, Gorham JD, Bundoc VG, Hodges MG, Jelinek I, Madala S, Karpati S, Mezey E (2010) Bone marrow stromal cells use TGF-beta to suppress allergic responses in a mouse model of ragweedinduced asthma. Proc Natl Acad Sci U S A 107:5652-5657

10. Liu K, Ji K, Guo L, Wu W, Lu H, Shan P, Yan C (2014) Mesenchymal stem cells rescue injured endothelial cells in an in vitro ischemia-reperfusion model via tunneling nanotube like structure-mediated mitochondrial transfer. Microvasc Res 92:10-18

11. Jackson MV, Morrison TJ, Doherty DF, McAuley DF, Matthay MA, Kissenpfennig A, O'Kane CM, Krasnodembskaya AD (2016) Mitochondrial transfer via tunneling nanotubes is an important mechanism by which mesenchymal stem cells enhance macrophage phagocytosis in the in vitro and in vivo models of ARDS. Stem Cells 34:2210-2223

12. Sohni A, Verfaillie CM (2013) Mesenchymal stem cells migration homing and tracking. Stem Cells Int 2013:130763

13. Curley GF, Ansari B, Hayes M, Devaney J, Masterson C, Ryan A, Barry F, O'Brien T, Toole DO, Laffey JG (2013) Effects of intratracheal mesenchymal stromal cell therapy during recovery and resolution after ventilator-induced lung injury. Anesthesiology 118:924-932

14. Hayes M, Curley GF, Masterson C, Devaney J, O'Toole D, Laffey JG (2015) Mesenchymal stromal cells are more effective than the MSC secretome in diminishing injury and enhancing recovery following ventilator-induced lung injury. Intensive Care Med Exp 3:29

15. VY-F S, Yang K-Y (2015) Mesenchymal stem cell-conditioned medium induces neutrophils apoptosis via inhibition of NFkB pathway and increases endogenous pulmonary stem cells in endotoxin-induced acute lung injury. Eur Respir J 46(suppl 59):OA3520

16. Ionescu L, Byrne RN, van Haaften T, Vadivel A, Alphonse RS, Rey-Parra GJ, Weissmann G, Hall A, Eaton F, Thebaud B (2012) Stem cell conditioned medium improves acute lung injury in mice: in vivo evidence for stem cell paracrine action. Am J Physiol Lung Cell Mol Physiol 303:L967-L977

17. Phinney DG, Pittenger MF (2017) Concise review: MSC-derived exosomes for cell-free therapy. Stem Cells 35:851-858 
18. Gong M, Yu B, Wang J, Wang Y, Liu M, Paul C, Millard RW, Xiao DS, Ashraf M, Xu M (2017) Mesenchymal stem cells release exosomes that transfer miRNAs to endothelial cells and promote angiogenesis. Oncotarget 8:4520045212

19. Chen QH, Liu AR, Qiu HB, Yang Y (2015) Interaction between mesenchymal stem cells and endothelial cells restores endothelial permeability via paracrine hepatocyte growth factor in vitro. Stem Cell Res Ther 6:44

20. Huang K, Kang X, Wang X, Wu S, Xiao J, Li Z, Wu X, Zhang W (2015) Conversion of bone marrow mesenchymal stem cells into type II alveolar epithelial cells reduces pulmonary fibrosis by decreasing oxidative stress in rats. Mol Med Rep $11: 1685-1692$

21. Grayson WL, Zhao F, Bunnell B, Ma T (2007) Hypoxia enhances proliferation and tissue formation of human mesenchymal stem cells. Biochem Biophys Res Commun 358:948-953

22. Dos Santos F, Andrade PZ, Boura JS, Abecasis MM, da Silva CL, Cabral JM (2010) Ex vivo expansion of human mesenchymal stem cells: a more effective cell proliferation kinetics and metabolism under hypoxia. J Cell Physiol 223:27-35

23. Nystedt J, Anderson H, Tikkanen J, Pietila M, Hirvonen T, Takalo R, Heiskanen A, Satomaa T, Natunen S, Lehtonen S Hakkarainen T, Korhonen M, Laitinen S, Valmu L, Lehenkari P (2013) Cell surface structures influence lung clearance rate of systemically infused mesenchymal stromal cells. Stem Cells 31:317-326

24. Bustos ML, Huleihel L, Kapetanaki MG, Lino-Cardenas CL, Mroz L, Ellis BM, McVerry BJ, Richards TJ, Kaminski N, Cerdenes N, Mora AL, Rojas M (2014) Aging mesenchymal stem cells fail to protect because of impaired migration and antiinflammatory response. Am J Respir Crit Care Med 189:787-798

25. Dighe PA, Viswanathan P, Mruthunjaya AK, Seetharam RN (2013) Effect of bFGF on HLA-DR expression of human bone marrow-derived mesenchymal stem cells. J Stem Cells 8:43-57

26. Moll G, Alm JJ, Davies LC, von Bahr L, Heldring N, Stenbeck-Funke L, Hamad OA, Hinsch R, Ignatowicz L, Locke M, Lonnies H, Lambris JD, Teramura Y, Nilsson-Ekdahl K, Nilsson B, Le Blanc K (2014) Do cryopreserved mesenchymal stromal cells display impaired immunomodulatory and therapeutic properties? Stem Cells 32:2430-2442

27. Song Y, Dou H, Li X, Zhao X, Li Y, Liu D, Ji J, Liu F, Ding L, Ni Y, Hou Y (2017) Exosomal miR-146a contributes to the enhanced therapeutic efficacy of interleukin-1 beta-primed mesenchymal stem cells against sepsis. Stem Cells 35:1208-122

28. Chen H, Min XH, Wang QY, Leung FW, Shi L, Zhou Y, Yu T, Wang CM, An G, Sha WH, Chen QK (2015) Pre-activation of mesenchymal stem cells with TNF-alpha, IL-1beta and nitric oxide enhances its paracrine effects on radiation-induced intestinal injury. Sci Rep 5:8718

29. Lee RH, Yoon N, Reneau JC, Prockop DJ (2012) Preactivation of human MSCs with TNF-alpha enhances tumorsuppressive activity. Cell Stem Cell 11:825-835

30. Han J, Lu X, Zou L, Xu X, Qiu H (2016) E-Prostanoid 2 receptor overexpression promotes mesenchymal stem cell attenuated lung injury. Hum Gene Ther 27:621-630

31. Martinez-Gonzalez I, Roca O, Masclans JR, Moreno R, Salcedo MT, Baekelandt V, Cruz MJ, Rello J, Aran JM (2013) Human mesenchymal stem cells overexpressing the IL-33 antagonist soluble IL-1 receptor-like-1 attenuate endotoxin-induced acute lung injury. Am J Respir Cell Mol Biol 49:552-562

32. Zhao X, Liu D, Gong W, Zhao G, Liu L, Yang L, Hou Y (2014) The toll-like receptor 3 ligand, poly(l:C), improves immunosuppressive function and therapeutic effect of mesenchymal stem cells on sepsis via inhibiting MiR-143. Stem Cells 32:521-533

33. Cai SX, Liu AR, Chen S, He HL, Chen QH, Xu JY, Pan C, Yang Y, Guo FM, Huang YZ, Liu L, Qiu HB (2016) The orphan receptor tyrosine kinase ROR2 facilitates MSCs to repair lung injury in ARDS animal model. Cell Transplant 25:1561-1574

34. Parekkadan B, Milwid JM (2010) Mesenchymal stem cells as therapeutics. Annu Rev Biomed Eng 12:87-117

35. Eggenhofer E, Benseler V, Kroemer A, Popp FC, Geissler EK, Schlitt HJ, Baan CC, Dahlke MH, Hoogduijn MJ (2012) Mesenchymal stem cells are short-lived and do not migrate beyond the lungs after intravenous infusion. Front Immunol 3:297

36. Yukawa H, Watanabe M, Kaji N, Okamoto Y, Tokeshi M, Miyamoto Y, Noguchi H, Baba Y, Hayashi S (2012) Monitoring transplanted adipose tissue-derived stem cells combined with heparin in the liver by fluorescence imaging using quantum dots. Biomaterials 33:2177-2186

37. Kean TJ, Lin P, Caplan Al, Dennis JE (2013) MSCs: delivery routes and engraftment, cell-targeting strategies, and immune modulation. Stem Cells Int 2013:732742

38. Ruster B, Gottig S, Ludwig RJ, Bistrian R, Muller S, Seifried E, Gille J, Henschler R (2006) Mesenchymal stem cells display coordinated rolling and adhesion behavior on endothelial cells. Blood 108:3938-3944

39. Teo GS, Yang Z, Carman CV, Karp JM, Lin CP (2015) Intravital imaging of mesenchymal stem cell trafficking and association with platelets and neutrophils. Stem Cells 33:265-277

40. Assis AC, Carvalho JL, Jacoby BA, Ferreira RL, Castanheira P, Diniz SO, Cardoso VN, Goes AM, Ferreira AJ (2010) Timedependent migration of systemically delivered bone marrow mesenchymal stem cells to the infarcted heart. Cell Transplant 19:219-230

41. Tan X, Gong YZ, Wu P, Liao DF, Zheng XL (2014) Mesenchymal stem cell-derived microparticles: a promising therapeutic strategy. Int J Mol Sci 15:14348-14363

42. Bian SY, Cui H, Zhang XN, Qi LP, Li DY (2012) Mesenchymal stem cells release membrane microparticles in the process of apoptosis. Zhongguo Shi Yan Xue Ye Xue Za Zhi 20:453-457

43. Ankrum JA, Ong JF, Karp JM (2014) Mesenchymal stem cells: immune evasive, not immune privileged. Nat Biotechnol 32:252-260

44. Badillo AT, Beggs KJ, Javazon EH, Tebbets JC, Flake AW (2007) Murine bone marrow stromal progenitor cells elicit an in vivo cellular and humoral alloimmune response. Biol Blood Marrow Transplant 13:412-422

45. Camp DM, Loeffler DA, Farrah DM, Borneman JN, LeWitt PA (2009) Cellular immune response to intrastriatally implanted allogeneic bone marrow stromal cells in a rat model of Parkinson's disease. J Neuroinflammation 6:17

46. Beggs KJ, Lyubimov A, Borneman JN, Bartholomew A, Moseley A, Dodds R, Archambault MP, Smith AK, Mclntosh KR (2006) Immunologic consequences of multiple, high-dose administration of allogeneic mesenchymal stem cells to baboons. Cell Transplant 15:711-721

47. Zangi L, Margalit R, Reich-Zeliger S, Bachar-Lustig E, Beilhack A, Negrin R, Reisner Y (2009) Direct imaging of immune rejection and memory induction by allogeneic mesenchymal stromal cells. Stem Cells 27:2865-2874 
48. Tolar J, O'Shaughnessy MJ, Panoskaltsis-Mortari A, McElmurry RT, Bell S, Riddle M, Mclvor RS, Yant SR, Kay MA, Krause D, Verfaillie CM, Blazar BR (2006) Host factors that impact the biodistribution and persistence of multipotent adult progenitor cells. Blood 107:4182-4188

49. Braid LR, Wood CA, Wiese DM, Ford BN (2018) Intramuscular administration potentiates extended dwell time of mesenchymal stromal cells compared to other routes. Cytotherapy 20:232-244

50. Chinnadurai R, Garcia MA, Sakurai Y, Lam WA, Kirk AD, Galipeau J, Copland IB (2014) Actin cytoskeletal disruption following cryopreservation alters the biodistribution of human mesenchymal stromal cells in vivo. Stem Cell Reports 3:60-72

51. Galleu A, Riffo-Vasquez Y, Trento C, Lomas C, Dolcetti L, Cheung TS, von Bonin M, Barbieri L, Halai K, Ward S, Weng L, Chakraverty R, Lombardi G, Watt FM, Orchard K, Marks DI, Apperley J, Bornhauser M, Walczak H, Bennett C, Dazzi F (2017) Apoptosis in mesenchymal stromal cells induces in vivo recipient-mediated immunomodulation. Sci Transl Med 15;9(416)

52. Nguyen PK, Riegler J, Wu JC (2014) Stem cell imaging: from bench to bedside. Cell Stem Cell 14:431-444

53. Myers JT, Petrosiute A, Huang AY (2014) Utilization of multiphoton imaging for real-time fate determination of mesenchymal stem cells in an immunocompetent mouse model. J Stem Cell Res Ther 4(7):1000217

54. Ghoroghchian PP, Therien MJ, Hammer DA (2009) In vivo fluorescence imaging: a personal perspective. Wiley Interdiscip Rev Nanomed Nanobiotechnol 1:156-167

55. Owens EA, Henary M, El Fakhri G, Choi HS (2016) Tissue-specific near-infrared fluorescence imaging. Acc Chem Res 49: $1731-1740$

56. Kim MH, Lee YJ, Kang JH (2016) Stem cell monitoring with a direct or indirect labeling method. Nucl Med Mol Imaging 50:275-283

57. Amarnath S, Foley JE, Farthing DE, Gress RE, Laurence A, Eckhaus MA, Metais JY, Rose JJ, Hakim FT, Felizardo TC, Cheng AV, Robey PG, Stroncek DE, Sabatino M, Battiwalla M, Ito S, Fowler DH, Barrett AJ (2015) Bone marrow-derived mesenchymal stromal cells harness purinergenic signaling to tolerize human Th1 cells in vivo. Stem Cells 33:1200-1212

58. Wolfs E, Verfaillie CM, Van Laere K, Deroose CM (2015) Radiolabeling strategies for radionuclide imaging of stem cells. Stem Cell Rev 11:254-274

59. Harney AS, Meade TJ (2010) Molecular imaging of in vivo gene expression. Future Med Chem 2:503-519

60. Willmann JK, Paulmurugan R, Rodriguez-Porcel M, Stein W, Brinton TJ, Connolly AJ, Nielsen CH, Lutz AM, Lyons J, Ikeno F, Suzuki Y, Rosenberg J, Chen IY, Wu JC, Yeung AC, Yock P, Robbins RC, Gambhir SS (2009) Imaging gene expression in human mesenchymal stem cells: from small to large animals. Radiology 252:117-127

61. Brooks A, Futrega K, Liang X, Hu X, Liu X, Crawford DHG, Doran MR, Roberts MS, Wang H (2018) Concise review: quantitative detection and modeling the in vivo kinetics of therapeutic mesenchymal stem/stromal cells. Stem Cells Transl Med 7:78-86

62. Chin BB, Nakamoto Y, Bulte JW, Pittenger MF, Wahl R, Kraitchman DL (2003) 111 In oxine labelled mesenchymal stem cell SPECT after intravenous administration in myocardial infarction. Nucl Med Commun 24:1149-1154

63. ten Berge RJ, Natarajan AT, Hardeman MR, van Royen EA, Schellekens PT (1983) Labeling with indium-111 has detrimental effects on human lymphocytes: concise communication. J Nuclear Med 24:615-620

64. Nowak B, Weber C, Schober A, Zeiffer U, Liehn EA, von Hundelshausen P, Reinartz P, Schaefer WM, Buell U (2007) Indium-111 oxine labelling affects the cellular integrity of haematopoietic progenitor cells. Eur J Nucl Med Mol Imaging 34:715-721

65. Devine SM, Cobbs C, Jennings M, Bartholomew A, Hoffman R (2003) Mesenchymal stem cells distribute to a wide range of tissues following systemic infusion into nonhuman primates. Blood 101:2999-3001

66. McBride C, Gaupp D, Phinney DG (2003) Quantifying levels of transplanted murine and human mesenchymal stem cells in vivo by real-time PCR. Cytotherapy 5:7-18

67. von Bahr L, Batsis I, Moll G, Hagg M, Szakos A, Sundberg B, Uzunel M, Ringden O, Le Blanc K (2012) Analysis of tissues following mesenchymal stromal cell therapy in humans indicates limited long-term engraftment and no ectopic tissue formation. Stem Cells 30:1575-1578

68. Sensebe L, Fleury-Cappellesso S (2013) Biodistribution of mesenchymal stem/stromal cells in a preclinical setting. Stem Cells Int 2013:678063

69. Ringden O, Uzunel M, Rasmusson I, Remberger M, Sundberg B, Lonnies H, Marschall HU, Dlugosz A, Szakos A, Hassan Z, Omazic B, Aschan J, Barkholt L, Le Blanc K (2006) Mesenchymal stem cells for treatment of therapy-resistant graftversus-host disease. Transplantation 81:1390-1397

70. Lan Y, Kodati S, Lee HS, Omoto M, Jin Y, Chauhan SK (2012) Kinetics and function of mesenchymal stem cells in corneal injury. Invest Ophthalmol Vis Sci 53:3638-3644

71. Schmuck EG, Koch JM, Centanni JM, Hacker TA, Braun RK, Eldridge M, Hei DJ, Hematti P, Raval AN (2016) Biodistribution and clearance of human mesenchymal stem cells by quantitative three-dimensional cryo-imaging after intravenous infusion in a rat lung injury model. Stem Cells Transl Med 5:1668-1675

72. Kawada M, Yoshimoto Y, Minamiguchi K, Kumagai H, Someno T, Masuda T, Ishizuka M, Ikeda D (2004) A microplate assay for selective measurement of growth of epithelial tumor cells in direct coculture with stromal cells. Anticancer Res 24:1561-1568

73. Kang SW, Lee S, Na JH, Yoon HI, Lee DE, Koo H, Cho YW, Kim SH, Jeong SY, Kwon IC, Choi K, Kim K (2014) Cell labeling and tracking method without distorted signals by phagocytosis of macrophages. Theranostics 4:420-431

74. Mahmood A, Lu D, Qu C, Goussev A, Chopp M (2005) Human marrow stromal cell treatment provides long-lasting benefit after traumatic brain injury in rats. Neurosurgery 57:1026-1031; discussion 1026-1031

75. Cao J, Hou S, Ding H, Liu Z, Song M, Qin X, Wang X, Yu M, Sun Z, Liu J, Sun S, Xiao P, Lv Q, Fan H (2016) In vivo tracking of systemically administered allogeneic bone marrow mesenchymal stem cells in normal rats through bioluminescence imaging. Stem Cells Int 2016:3970942

76. Yu W, Sandoval RM, Molitoris BA (2005) Quantitative intravital microscopy using a generalized polarity concept for kidney studies. Am J Physiol Cell Physiol 289:C1197-C1208

77. Nyman LR, Wells KS, Head WS, McCaughey M, Ford E, Brissova M, Piston DW, Powers AC (2008) Real-time, multidimensional in vivo imaging used to investigate blood flow in mouse pancreatic islets. J Clin Invest 118:3790-3797

78. Pinner S, Jordan P, Sharrock K, Bazley L, Collinson L, Marais R, Bonvin E, Goding C, Sahai E (2009) Intravital imaging reveals transient changes in pigment production and Brn2 expression during metastatic melanoma dissemination. Cancer Res 69:7969-7977 
79. Weigert R, Sramkova M, Parente L, Amornphimoltham P, Masedunskas A (2010) Intravital microscopy: a novel tool to study cell biology in living animals. Histochem Cell Biol 133:481-491

80. Alexander S, Weigelin B, Winkler F, Friedl P (2013) Preclinical intravital microscopy of the tumour-stroma interface: invasion, metastasis, and therapy response. Curr Opin Cell Biol 25:659-671

81. Gligorijevic B, Condeelis J (2009) Stretching the timescale of intravital imaging in tumors. Cell Adhes Migr 3:313-315

82. Kedrin D, Gligorijevic B, Wyckoff J, Verkhusha W, Condeelis J, Segall JE, van Rheenen J (2008) Intravital imaging of metastatic behavior through a mammary imaging window. Nat Methods 5:1019-1021

83. Tabuchi A, Mertens M, Kuppe H, Pries AR, Kuebler WM (2008) Intravital microscopy of the murine pulmonary microcirculation. J Appl Physiol 104:338-346

84. Toma C, Wagner WR, Bowry S, Schwartz A, Villanueva F (2009) Fate of culture-expanded mesenchymal stem cells in the microvasculature: in vivo observations of cell kinetics. Circ Res 104:398-402

85. Looney MR, Bhattacharya J (2014) Live imaging of the lung. Annu Rev Physiol 76:431-445

86. Piper SK, Habermehl C, Schmitz CH, Kuebler WM, Obrig H, Steinbrink J, Mehnert J (2013) Towards whole-body fluorescence imaging in humans. PLoS One 8:e83749

87. Ray P, De A, Min JJ, Tsien RY, Gambhir SS (2004) Imaging tri-fusion multimodality reporter gene expression in living subjects. Cancer Res 64:1323-1330

88. Hoffman RM, Yang M (2006) Whole-body imaging with fluorescent proteins. Nat Protoc 1:1429-1438

89. Li Z, Shi J, Zhang H, Sun M (2014) Highly controllable synthesis of near-infrared persistent luminescence SiO2/ CaMgSi2O6 composite nanospheres for imaging in vivo. Opt Express 22:10509-10518

90. Lecuyer T, Teston E, Ramirez-Garcia G, Maldiney T, Viana B, Seguin J, Mignet N, Scherman D, Richard C (2016) Chemically engineered persistent luminescence nanoprobes for bioimaging. Theranostics 6:2488-2524

91. Barbash IM, Chouraqui P, Baron J, Feinberg MS, Etzion S, Tessone A, Miller L, Guetta E, Zipori D, Kedes LH, Kloner RA, Leor J (2003) Systemic delivery of bone marrow-derived mesenchymal stem cells to the infarcted myocardium: feasibility, cell migration, and body distribution. Circulation 108:863-868

92. Allers C, Sierralta WD, Neubauer S, Rivera F, Minguell JJ, Conget PA (2004) Dynamic of distribution of human bone marrow-derived mesenchymal stem cells after transplantation into adult unconditioned mice. Transplantation 78:503-508

93. Gao J, Dennis JE, Muzic RF, Lundberg M, Caplan Al (2001) The dynamic in vivo distribution of bone marrow-derived mesenchymal stem cells after infusion. Cells Tissues Organs 169:12-20

94. Makela T, Takalo R, Arvola O, Haapanen H, Yannopoulos F, Blanco R, Ahvenjarvi L, Kiviluoma K, Kerkela E, Nystedt J, Juvonen T, Lehenkari P (2015) Safety and biodistribution study of bone marrow-derived mesenchymal stromal cells and mononuclear cells and the impact of the administration route in an intact porcine model. Cytotherapy 17:392-402

95. Cheng SH, Yu D, Tsai HM, Morshed RA, Kanojia D, Lo LW, Leoni L, Govind Y, Zhang L, Aboody KS, Lesniak MS, Chen CT, Balyasnikova IV (2016) Dynamic In Vivo SPECT Imaging of Neural Stem Cells Functionalized with Radiolabeled Nanoparticles for Tracking of Glioblastoma. J Nuclear Med 57:279-284

96. Gholamrezanezhad A, Mirpour S, Bagheri M, Mohamadnejad M, Alimoghaddam K, Abdolahzadeh L, Saghari M, Malekzadeh R (2011) In vivo tracking of 111 In-oxine labeled mesenchymal stem cells following infusion in patients with advanced cirrhosis. Nucl Med Biol 38:961-967

97. Jelicks LA, Tanowitz HB, Albanese C (2013) Small animal imaging of human disease: from bench to bedside and back. Am J Pathol 182:294-295

98. Lopez-Santalla M, Mancheno-Corvo P, Escolano A, Menta R, Delarosa O, Redondo JM, Bueren JA, Dalemans W, Lombardo E, Garin MI (2018) Comparative analysis between the in vivo biodistribution and therapeutic efficacy of adipose-derived mesenchymal stromal cells administered intraperitoneally in experimental colitis. Int J Mol Sci 19(7):1853

99. Scott B, Sanders CL, Mitchel REJ, Boreham DR (2008) CT scans may reduce rather than increase the risk of Cancer. J Am Physicians Surgeons 13(1):8-11.

100. Fabritius G, Brix G, Nekolla E, Klein S, Popp HD, Meyer M, Glatting G, Hagelstein C, Hofmann WK, Schoenberg SO, Henzler T (2016) Cumulative radiation exposure from imaging procedures and associated lifetime cancer risk for patients with lymphoma. Sci Rep 6:35181

101. Schrepfer S, Deuse T, Reichenspurner H, Fischbein MP, Robbins RC, Pelletier MP (2007) Stem cell transplantation: the lung barrier. Transplant Proc 39:573-576

102. Fischer UM, Harting MT, Jimenez F, Monzon-Posadas WO, Xue H, Savitz SI, Laine GA, Cox CS Jr (2009) Pulmonary passage is a major obstacle for intravenous stem cell delivery: the pulmonary first-pass effect. Stem Cells Dev 18: 683-692

103. Furlani D, Ugurlucan M, Ong L, Bieback K, Pittermann E, Westien I, Wang W, Yerebakan C, Li W, Gaebel R, Li RK, Vollmar B, Steinhoff G, Ma N (2009) Is the intravascular administration of mesenchymal stem cells safe? Mesenchymal stem cells and intravital microscopy. Microvasc Res 77:370-376

104. Forest VF, Tirouvanziam AM, Perigaud C, Fernandes S, Fusellier MS, Desfontis JC, Toquet CS, Heymann MF, Crochet DP, Lemarchand PF (2010) Cell distribution after intracoronary bone marrow stem cell delivery in damaged and undamaged myocardium: implications for clinical trials. Stem Cell Res Ther 1:4

105. Vulliet PR, Greeley M, Halloran SM, MacDonald KA, Kittleson MD (2004) Intra-coronary arterial injection of mesenchymal stromal cells and microinfarction in dogs. Lancet 363:783-784

106. Freyman T, Polin G, Osman H, Crary J, Lu M, Cheng L, Palasis M, Wilensky RL (2006) A quantitative, randomized study evaluating three methods of mesenchymal stem cell delivery following myocardial infarction. Eur Heart J 27:1114-1122

107. Jackson JS, Golding JP, Chapon C, Jones WA, Bhakoo KK (2010) Homing of stem cells to sites of inflammatory brain injury after intracerebral and intravenous administration: a longitudinal imaging study. Stem Cell Res Ther 1:17

108. Chen Y, Xiang LX, Shao JZ, Pan RL, Wang YX, Dong XJ, Zhang GR (2010) Recruitment of endogenous bone marrow mesenchymal stem cells towards injured liver. J Cell Mol Med 14:1494-1508

109. Ge J, Guo L, Wang S, Zhang Y, Cai T, Zhao RC, Wu Y (2014) The size of mesenchymal stem cells is a significant cause of vascular obstructions and stroke. Stem Cell Rev 10:295-303

110. Potapova IA, Brink PR, Cohen IS, Doronin SV (2008) Culturing of human mesenchymal stem cells as three-dimensional aggregates induces functional expression of CXCR4 that regulates adhesion to endothelial cells. J Biol Chem 283:1310013107 
111. Shi M, Li J, Liao L, Chen B, Li B, Chen L, Jia H, Zhao RC (2007) Regulation of CXCR4 expression in human mesenchymal stem cells by cytokine treatment: role in homing efficiency in NOD/SCID mice. Haematologica 92:897-904

112. Thankamony SP, Sackstein R (2011) Enforced hematopoietic cell E- and L-selectin ligand (HCELL) expression primes transendothelial migration of human mesenchymal stem cells. Proc Natl Acad Sci U S A 108:2258-2263

113. Sackstein R, Merzaban JS, Cain DW, Dagia NM, Spencer JA, Lin CP, Wohlgemuth R (2008) Ex vivo glycan engineering of CD44 programs human multipotent mesenchymal stromal cell trafficking to bone. Nat Med 14:181-187

114. Yang JX, Zhang N, Wang HW, Gao P, Yang QP, Wen QP (2015) CXCR4 receptor overexpression in mesenchymal stem cells facilitates treatment of acute lung injury in rats. J Biol Chem 290:1994-2006

115. Wynn RF, Hart CA, Corradi-Perini C, O'Neill L, Evans CA, Wraith JE, Fairbairn LJ, Bellantuono I (2004) A small proportion of mesenchymal stem cells strongly expresses functionally active CXCR4 receptor capable of promoting migration to bone marrow. Blood 104:2643-2645

116. Ponte AL, Marais E, Gallay N, Langonne A, Delorme B, Herault O, Charbord P, Domenech J (2007) The in vitro migration capacity of human bone marrow mesenchymal stem cells: comparison of chemokine and growth factor chemotactic activities. Stem Cells 25:1737-1745

117. Shuai Y, Liao L, Su X, Yu Y, Shao B, Jing H, Zhang X, Deng Z, Jin Y (2016) Melatonin treatment improves mesenchymal stem cells therapy by preserving Stemness during long-term in vitro expansion. Theranostics 6:1899-1917

118. Tang Y, Cai B, Yuan F, He X, Lin X, Wang J, Wang Y, Yang GY (2014) Melatonin pretreatment improves the survival and function of transplanted mesenchymal stem cells after focal cerebral ischemia. Cell Transplant 23:1279-1291

119. Somanna NK, Worner PM, Murthy SN, Pankey EA, Schachtele DJ, St Hilaire RC, Jansen D, Chaffin AE, Nossaman BD, Alt EU, Kadowitz PJ, Izadpanah R (2014) Intratracheal administration of cyclooxygenase-1-transduced adipose tissue-derived stem cells ameliorates monocrotaline-induced pulmonary hypertension in rats. Am J Phys Heart Circ Phys 307:H1187$\mathrm{H} 1195$

120. Squillaro T, Peluso G, Galderisi U (2016) Clinical trials with mesenchymal stem cells: An update. Cell Transplant 25:829-848

121. Bauer S (2018) Are stem cells ready for prime time? A look at FDA research advances in Regenerative Medicine

122. Agency EM (2008) Guideline on Human Cell-Based Medicinal Products. European Medicines Agency, London

123. Zheng B, von See MP, Yu E, Gunel B, Lu K, Vazin T, Schaffer DV, Goodwill PW, Conolly SM (2016) Quantitative magnetic particle imaging monitors the transplantation, biodistribution, and clearance of stem cells in vivo. Theranostics 6:291-301

124. Bansal A, Pandey MK, Demirhan YE, Nesbitt JJ, Crespo-Diaz RJ, Terzic A, Behfar A, DeGrado TR (2015) Novel (89)Zr cell labeling approach for PET-based cell trafficking studies. EJNMMI Res 5:19

125. Harris DM, Hazan-Haley I, Coombes K, Bueso-Ramos C, Liu J, Liu Z, Li P, Ravoori M, Abruzzo L, Han L, Singh S, Sun M, Kundra V, Kurzrock R, Estrov Z, Rojas M (2011) Transformation of Human Mesenchymal Cells and Skin Fibroblasts into Hematopoietic Cells. PLOS ONE 6(6):e21250

126. Lin P, Correa D, Kean TJ, Awadallah A, Dennis JE, Caplan Al (2014) Serial transplantation and long-term engraftment of intra-arterially delivered clonally derived mesenchymal stem cells to injured bone marrow. Molecular Therapy 22:160-168

127. Park I, Choe K, Seo H, Hwang Y, Song E, Ahn J, Hwan Jo Y, Kim P (2018) Intravital imaging of a pulmonary endothelial surface layer in a murine sepsis model. Biomedical Optics Express 9:2383-2393

128. Sun Z, Wang C, Shi C, Sun F, Xu X, Qian W, Nie S, Han X (2014) Activated Wnt signaling induces myofibroblast differentiation of mesenchymal stem cells, contributing to pulmonary fibrosis. Int J Mol Med 33:1097-1109

\section{Submit your manuscript to a SpringerOpen ${ }^{\circ}$ journal and benefit from:}

- Convenient online submission

- Rigorous peer review

- Open access: articles freely available online

- High visibility within the field

Retaining the copyright to your article

Submit your next manuscript at $\boldsymbol{\nabla}$ springeropen.com 